Article

\title{
Accounting Treatment of R\&D for Environmentally Responsible Firms: Evidence from South Korea
}

\author{
Suyon Kim ${ }^{1}\left[\right.$ and Jaehong Lee ${ }^{2, *}$ \\ 1 Department of Accounting, Jeonbuk National University, Jeonju 54896, Korea; sykim309@jbnu.ac.kr \\ 2 Division of Accounting/Tax and Management Information Systems, Kyonggi University, Suwon 16227, Korea \\ * Correspondence: jhong@kyonggi.ac.kr
}

Received: 18 March 2020; Accepted: 20 April 2020; Published: 22 April 2020

\begin{abstract}
The purpose of this paper is to investigate the relationship between corporate environmental responsibility (CER) and R\&D accounting treatment. Using firms listed in the Korea Stock Exchange (KSE) market between the years 2014 and 2018, this study not only investigates this relationship but also expands upon CER activities in various aspects, such as environmental performance strategy, environmental performance organization, and environmental shareholders. Furthermore, the positive association between various $C E R$ activities and $R \& D$ capitalization is significant in a highly competitive market. This relationship is robust with an alternative measure of CER activities and firm-fixed effects. This result implies that firms participating in CER activities focus on sustainable commercial success, unlike other firms.
\end{abstract}

Keywords: corporate environmental responsibility (CER); competitive product market; research and development (R\&D) capitalization; accounting treatment; sustainability

\section{Introduction}

Recently, corporate social responsibility (CSR) has become one of the most significant and common corporate trends. With mandatory annual reports, international companies such as Nike, Microsoft, and PepsiCo voluntarily publish sustainability reports, alongside their mandatory annual reports, to achieve sustainable growth. Recent research shows a positive correlation between CSR performance and its value, suggesting that the transition to CSR is more a strategic choice than an altruistic one.

There are two key theories about the relationship between CSR and corporate value: slack resources theory and good management theory. Slack theory explains that the firms choose social investment opportunities due to available or free resources, slack resources [1]. In other words, this theory suggests that there is a positive relationship between financial performance and the amount of available slack resources. Another theory is the good management theory, which suggests that management practices continuously seek better ways to improve social performances, by strengthening the relationship with important stakeholders.

With a significant increase in CSR activities since 2011, the Korea Corporate Governance Service (hereafter KCGS) provides environmental, social, and governance (hereafter ESG) scores, aiming to obtain insightful views on corporate governance and socially responsible management practices. This ESG evaluation model is in accordance with international standards such as the principles of the Organization for Economic Cooperation and Development (OECD) regarding corporate governance and ISO26000, but it also reflects legal and managerial settings in South Korea.

The motivations of CSR activities are debatable, and their effects are vague. CSR is a broad and abstract concept that companies should pursue through policies and decision-making, or by following policies that are aligned with the objectives and values of society [2]. At the same time, using an aggregate measure for CSR activities leads to ambiguous, inconclusive, or unintended mixed results. Firms may, 
to some extent, adapt their practices to the demands of society by simultaneously promoting a green image. For example, SK Hynix has decided to provide incentives to the primary partner companies that create social value [3]. However, while the previous literature on CSR supports traditional innovation, the latter might not translate into actual environmental investment [4].

Thus, this study focuses on corporate environmental responsibility (hereafter CER) distinguished from corporate social responsibility, as proposed by the World Business Council for Sustainable Development (WBCSD) [5,6]. KCGS solely provides ESG scores and E, S, and G rating scores to measure the level of sustainable management that is listed in Korea. By providing scores, it promotes sustainable growth and transparency as regards the degree to which a firm is actively engaged in developing sustainable processes, thereby maximizing corporate value. Among them, CER activities refer to environmental aspects and consist of performance management, performance reporting, and stakeholder engagement.

Prior studies have reported that CER activities are often considered to be a part, result, or spin-off of more comprehensive CSR activities [7]. However, CER activities are the set of practices carried out by firms that benefit or mitigate the negative impacts of business on the environment and that go beyond the minimum that companies are legally required to do [8]. Adequate investment in CER activities leads to more efficient processes and improve productivity [9]. In response to growing concerns about environmental sustainability, the International Finance Corporation (IFC) has established a sustainability framework and set standards for the performance of environmental responsibility. By meeting these standards, firms can effectively increase their competitive advantage and develop opportunities for growth and development [10].

It is important to understand the impact of CER activities on the accounting information that impacts a firm's operation. When a firm improves its CER activities, the information asymmetry between shareholders and management is reduced by improved accounting information [11]. An enhanced information environment and increased monitoring of management should result in enhanced innovation for achieving the sustainability of a firm.

In the pursuit of innovation, firms are aware of the impact of environmental activities and increasingly motivated by environmental concerns [12]. R\&D investments and improvements in a company's innovative capacity are important drivers of eco-innovations that make firms economically successful [13]. Environmental innovation through R\&D is one of the means for future growth, the development of which can improve and expand firms' operations [14], thereby gaining a competitive advantage.

There are two accounting treatments regarding R\&D: expensing and capitalizing. Capitalizing on $R \& D$ expenditures conveys the information about the success of the projects to the market, which in turn affects investors' beliefs about R\&D future payoffs. In addition, it is more informative than expensed $R \& D$, due to the requirement of reasonable future estimation [15]. R\&D capitalization also makes it more likely that managers will provide a rationalization for their beliefs about future benefits [16].

In this study, we examined the correlation between CER activities on the capitalization of R\&D expenditures using a sample of 2909 firm-year observations from South Korea firms between 2014 and 2018. The results of this study indicate that firms participating in CER activities likely capitalize on $R \& D$ expenditures, with a strong belief in future opportunities for commercial success [17], which supports the first hypothesis. This relationship is more pronounced in a highly competitive market, implying that CER activities may act as additional product differentiators [18], gaining competitive advantage in the market. This is in alignment with the second hypothesis.

This study makes several distinctive contributions. First, the existing literature has primarily focused on overall CER activities but paid less attention to CER activities in detail, due to a lack of availability of specific data. However, our study extends the CER literature by distinguishing between overall and specific CER activities. At the same time, this study adds to the latest literature on CER activities, competitive markets, and R\&D accounting choices. Whereas the data on CER activities used 
in most of the prior studies are quantified at each researcher's discretion, the data used in this study are internal data, scored accurately by KCGS.

Second, managers are responsible for the allocation of the limited resources of a corporation and need a thorough understanding of those resources. With these findings, managers focusing on specific CER activities, such as strategy, organization, and shareholder, can contribute to the financial performance of their company to maximize the impact of investment in CER activities.

Third, this research differs from previous studies in that it uses recent competition and focuses on a more recent time period (2014-2018), that contains the most comprehensive data provided by the KCGS.

The remainder of the paper is organized as follows: Section 2 describes the review of literature, Section 3 presents the data and method description, Section 4 presents the empirical results, and Section 5 presents the conclusion.

\section{Backgrounds and Hypotheses}

\subsection{Corporate Environmental Responsibility (CER)}

Social pressure has driven companies to a more ethical mode of operation in recent years, and many businesses now focus on environment. In 1997, the Kyoto Protocol adopted the United Nations Framework Convention on Climate Change, and since then, many financial institutions have also transitioned to more environmentally friendly investment strategies, such as the principle for responsible investment (PRI), which emphasize corporate responsibility by considering non-financial risks such as environmental effects when making investments. These firms have therefore both amplified the importance of environmental impact when considering the corporate sustainability of a company and highlighted its function as a strategy for growth.

In line with the worldwide trends, the KCGS began publishing codes of best practice for sustainable operation, in order to raise awareness and encourage the practice of social responsibility in South Korea, and on 1 October 2010, the Korea Exchange introduced its environmentally responsible investment index, called Social Responsible Index-Eco (KRX SRI-ECO). The following year, the KCGS went a step further, introducing environmental scores. Environmental responsibility encourages sustainable growth through planning, engaging with stakeholders, proper execution, competent management, and transparent reporting of the performance of the company. The index exists in order to make the environmental practices of companies transparent to investors, which has the effect of improving corporate performance and value by encouraging sustainable operations.

According to the KCGS, CER activities present the future direction of environmental management, toward which Korean companies should aim, as environmental issues become key factors to business sustainability. CER activities are to raise awareness of environmental management, improve corporate governance, increase corporate value, and establish sustainable management strategies [19]. Environmentally responsible behaviors promote the protection of the environment, sustainable development, the efficient use of natural resources, and waste and pollution management. CER activities require firms to mitigate the negative impacts on the environment beyond what is legally required.

Prior studies have found that CER activities have a significant effect on firm performance [20-22]. Suganthi [20] stresses the importance of adopting green practices within the organization and implementing CSR initiatives among stakeholders to improve performance. Moreover, protecting the environment is most important among all stakeholders in today's globalized economy. Using data of European listed firms, Orazalin and Baydauletov [21] indicate that firms with effective CSR are more involved in corporate environmental performance. In addition, firms with female directors on the board exhibit better environmental performance. Zeng et al. [22] study the impact of corporate environmental responsibility on investment efficiency using a Chinese listed company from 2011 to 2016. They show that corporate environmental responsibility significantly affects investment efficiency, and this relationship improves with a good institutional environment. 


\subsection{Prior Research on RED Accounting Treatment}

South Korea adopted the International Financial Reporting Standards (IFRS) in 2011. According to paragraph 10 of K-IFRS 1038 Intangible assets 57, research and development (R\&D) accounting is faced with a dichotomous choice between capitalizing and expensing in the development phase, provided the appropriate conditions are met. The conditions are as follows: (1) technical feasibility of completing the development; (2) the intention to complete the development; (3) the pattern of future economic benefits or the usefulness for internal use; (4) the availability of adequate technical and financial resources to complete the development; and (5) the capability to measure development expenditure separately and reliably [23]. Considerable flexibility is left to the managers, even though these requirements for the capitalization R\&D are clear. For example, the probability of the technical feasibility of completing the development and the intention to complete development depend on an estimation, which is subject to managerial incentives. Therefore, managers may abuse this discretion to hide poor performance and inflate income [14], in an attempt to inflate the value of the firm.

Outside of Korea, capitalization has been implemented in certain circumstances. For example, in the U.S. all R\&D expenditures are expensed immediately with the exception of software companies [24,25]. Internationally, IAS No. 38 requires all research costs to be expensed, while firms are to capitalize on development costs after reaching technical and commercial feasibility [26], though this was not officially required. In August 2001, FASB suggested that information about intangibles be reported in financial statements in order to improve information quality [27].

In answering the IASB's request for more research on intangibles, Ciftci and Zhou [28] investigate the association between intangible-intensive firms and the value relevance of financial information improvement. Consistent with the belief that R\&D capitalization serves as a signal, Healy et al. [29], using data from 500 firms over 32 years, suggest that capitalizing R\&D is more highly correlated with economic returns and values than expensing it. Padgett and Galan [30] show that R\&D intensity affects CSR positively, suggesting that $R \& D$ is considered as a form of investment that leads to product and process innovation. They suggest that the effect of R\&D intensity on CSR is significant and positive in manufacturing industries. Furthermore, using a sample of Israeli high-technology and science-based firms, Chen et al. [31] find that R\&D capitalization is highly significant in relation to stock prices and enhances the relevance of voluntary disclosures. Using firms in South Korea, Lee [32] suggests that the firms in the biotech industry tend to maintain a constant level of R\&D capitalization. This may be driven by the motivation of earnings management, as R\&D has a direct impact on the increase of profitability and value, implying that the capitalization of R\&D provides more information about future earnings.

Among the two accounting choices of $R \& D$, capitalizing or expensing, these findings support the argument that R\&D capitalization plays a positive role in conveying relevant information that helps financial statement users make decisions. Outlaying the capitalization of R\&D expenditures on the Statement of Financial Position, instead of expensing it on the Income Statement, results in an instant increase of profit and market-value boosting. Therefore, the firms that choose R\&D capitalization anticipate future sustainable success.

However, R\&D capitalization is not always informative, because many aspects of $R \& D$, such as technical feasibility, are unobservable and difficult to forecast. Moreover, managers are often uncertain when it comes to the success and future benefits of specific R\&D expenditures. Addressing such uncertainties is left to the managers' discretion, which allows for the possibility of earnings manipulation. There are a number of studies that support this view. Percy [33] finds that managers in firms with information asymmetry and agency costs are likely to capitalize on R\&D expenditures. In the same vein, Markarian et al. [34] report that Italian listed companies opportunistically capitalize on R\&D expenditures in order to smooth earnings. 


\subsection{Hypothesis Development}

CER activities are the set of practices by firms that benefit or mitigate the negative impacts of business on the environment. Adequate investment in CER activities is associated with various aspects of firm performances: it leads to more efficient processes and productivity, encourages innovation, improves morale, and promotes the efficient use of resources [9]. It also strengthens sustainable management and decreases uncertainty in future cash flows [35].

Achieving an environmentally competitive advantage over other competitors in the market, R\&D can be a major strategic tool, resulting in environmental innovation. The subject of countless studies, investment in R\&D is the core activity for a firm's sustainable growth and a primary force in the creation of firm value. When it comes to R\&D, managers have a dichotomous choice between capitalizing and expensing in the development phase, each of which features completely different investment decision processes, motivations, and impacts on financial statements.

$R \& D$ capitalization is more informative than expensing because it requires future benefit estimation [15]. R\&D capitalization is also believed to offer a competitive advantage through improvements of the firm in the long run [36]. The decision to capitalize on R\&D has multiple implications, one of which may be that managers are likely to convey their beliefs about possible future outcomes arising from the R\&D activities [16].

In line with the study of McWilliams and Siegel [36], it is inferred that CSR and R\&D intensity are positively correlated, due to product and process innovation. For instance, various firms make an effort to minimize waste and pollution by adopting new environmental-friendly management systems and processes. Such innovation can be achieved through R\&D investment. Despite the dichotomous accounting choice of R\&D, its capitalization is based on a strong belief in future opportunities for commercial success. Thus, in this study, we attempt to examine the relationship between CER activities and R\&D capitalization. The first hypothesis is as follows:

Hypothesis 1. There is a positive correlation between CER activities and RED capitalization.

The second hypothesis expands the first hypothesis and analyzes the correlation between firms participating in CER activities and R\&D capitalization. Economic theory assumes that managers of product market competition disciplines are averse to risk and effort $[37,38]$. The competition also thins profit margins, thus limiting the amount of resources managers can divert for their own interests, which means competition may be considered to be an external control device.

The level of market competition affects the managerial decisions of firms and is, therefore, an important determinant of firm profitability [39]. When competition acts as a disciplinary mechanism, managerial slack may be reduced. When competition increases, managers are implicitly motivated to work harder, as competitors make firms better informed and more capable of evaluating the actions of managers [38]. In a highly competitive market, managers need to differentiate their products from those of competitors. Sheikh [40] shows that CEOs managing investments chose to increase their investment in innovation when companies were in a competitive market.

By investing in CER activities, firms differentiate themselves from competitors, thereby attaining greater market shares. Fisman et al. [41] find that firms in highly competitive markets are more likely to invest in CER activities than those in uncompetitive markets because when the competition is high, advantages are more pronounced [42,43]. Therefore, the competition gives firms that engage in CER activities a competitive advantage [44], and in highly competitive industries, managers must gain that advantage in order to increase firm value and secure their position.

On the other hand, some studies have found that high levels of competition force managers to prioritize short-term gains and projects with positive net present values in order to increase shareholder returns [45]. Also, Siegel and Vitaliano [43], from a more theoretical perspective, argue that in a market in which competition is perfectly balanced, all firms would equally invest in CSR, canceling out any advantage otherwise gained. 
Regardless, it is clear that the market has a significant impact on the relationship between CER activities and capitalization on R\&D expenditures, which brings us to our next hypothesis.

Hypothesis 2. The degree of product market competition influences the relationship between CER activities and $R \mathcal{E D}$ capitalization.

\section{Research Design and Sample Description}

\subsection{Corporate Environmental Responsibility (CER)}

This study focuses primarily on CER activities, which account for the environmental management of a company as a key factor in its long-term sustainability. The KCGS provides an environmental score and encourages interest in sustainability by not only evaluating, but also recommending firms that engage in socially responsible practices.

CER activities evaluate the degree to which firms are environmentally engaged at various levels, in order to achieve corporate sustainability and to maximize corporate value. In other words, CER activities evaluate whether a firm establishes an environmental-friendly production system, such as a gas emission control system, while strengthening the environmental capabilities of its supply chain to maximize firm value.

The major evaluation criteria of CER activities are environmental performance strategy (E1), performance organization (E2), and shareholders (E3). The evaluation model has been independently developed by the KCGS, aligned not only with international standards such as OECD principles on corporate governance and ISO2000, but also with legal and management circumstances in Korea. In the course of the evaluation, more than 900 raw data are collected per company, such as corporate disclosure (for example, business reports, sustainability reports, and websites), materials from regulatory bodies and municipalities, and media coverage.

The details of each score are as follows. An environmental performance strategy evaluates whether or not a firm's environmental strategy is in harmony with the company's basic management strategies and policies. Its major indicators are (1) environmental-friendly strategies and policies and (2) investment in the environment. It is a detailed evaluation of the firm's plan, fulfillment, and sustaining investment ratio.

Environmental performance organization evaluates the degree to which firms have established an organization to implement environmental management systems and activities and whether or not those activities are advised by its board of directors. Its major evaluation areas are (1) a review of environmental management activities by the board of directors, (2) environmental organization, which accounts for both enterprise decision-making organization and actual working organization, and (3) environmental education.

The environmental shareholder index evaluates the degree to which firms disclose environmental information as a means of communication that reflects the opinion of shareholders. The major indicators are (1) communication programs with stakeholders, (2) environmental information disclosure, (3) the firm's support and cooperation in local environmental conservation activities, and (4) the membership of an international initiative.

This study considers each of the aforementioned CER activity indicators, based on the highly detailed data provided by the KCGS. In addition, each CER activity has a full score, based on the criteria given by the guidelines mentioned above.

\subsection{Product Market Competition}

In this study, the Herfindahl-Hirschman Index (HHI) is used to measure the level of competitiveness of the market. The HHI measure is commonly used in research to explain the competitive structure and market concentration among firms in a specific group. In a study by Sutton [46], HHI is used to measure the degree of competition, and it is widely used in studies of finance [47]. 
In this study, the HHI, calculated as the sum of squared market shares, is used to measure market competition, through the following model:

$$
H H I=\sum_{i=1}^{I} s_{i j t}{ }^{2}
$$

where $S_{i j t}$ equals the market share of firm $i$ in industry $j$ in year $t$.

To measure competition, the market share for each firm, relative to the total net sales of firms across its industry, is calculated. These values are then square rooted and added together for each industry, according to the SIC classification code. HHI values and market competition are negatively correlated.

\subsection{Empirical Models}

To test Hypothesis 1, we analyze the correlation between CER activities and R\&D capitalization, including several control variables in the following model to eliminate any spurious effects. $R \& D$ capitalization is calculated as the asset-counted R\&D expenditures divided by the total assets [48].

$$
\begin{aligned}
\text { ARND }_{t} & =\beta_{0}+\beta_{1} E 1 \sim 3_{t}+\beta_{2} \text { SIZE }_{t}+\beta_{3} R O A_{t}+\beta_{4} M K T_{t}+\beta_{5} L_{O S S} \\
& +\beta_{7} O C F_{t}+\beta_{6} G R O W T H_{t}+\beta_{7} I N V R E C_{t}+I N D \text { dummy }+Y R \text { dummy }+\varepsilon
\end{aligned}
$$

where $A R N D=A$ dummy variable equal to 1 if the capitalized R\&D divided by the total assets is higher than the mean; E1 = Environmental performance strategy score; E2 = Environmental performance organization score; E3 = Environmental stakeholder score; SIZE = Ln(total assets); ROA = Net income/total assets; MKT $=1$ if listed in Kosdaq, 0 otherwise; LOSS $=1$ for a company with losses, and 0 otherwise; $\mathrm{OCF}=$ Operating cash flow/total assets; INVREC = Plant, property, and equipment (except land and construction in the process) divided by the total assets.

ARND is a dummy variable equal to 1 if the capitalized R\&D divided by the total assets is lower than the mean. Otherwise, it is coded as 0 . Though the categorization may be arbitrary, this study focuses on meaningful qualitative differences between the groups rather than analyzing the linear relationship between corporate environmental responsibility and the capitalized R\&D amount.

Based on the relevant literature, control variables such as firm size and financial leverage are used. By doing so, the possible omitted variable bias is presumably minimized. One of the control variables used in the model is SIZE, representing firm size, calculated as the natural log of total assets. ROA and LOSS are also included to control the firms' performance and risk, respectively. To control the volatility by industry and year, industry dummy is included. At the same time, the year dummy is included to manage the volatility caused by specific economic conditions within a particular year.

\subsection{Sample Selection}

The study includes all companies listed in the Korea Stock Exchange (KSE) with accounts closing in December from 2014 to 2018 as the initial sample. Data on scores of CER activities are purchased from the Korea Corporate Governance Service (KCGS), the sole provider. Moreover, in the initial sample, the firms with a business combination are excluded. The acquirer recognizes the intangible assets at the date of acquisition, irrespective of whether the acquiree recognized the assets or expenses before business combination. In other words, even if the acquiree recognized R\&D expenditure as an expense, the acquirer recognizes it as an asset.

The financial data is collected from the FnGuide database, and CER indexes are obtained from the Korea Corporate Governance Service (KCGS). Firms with inexistent or incomplete financial data and firms in the financial industry are eliminated. In addition, the top and bottom $1 \%$ of independent and dependent variables are winsorized in order to minimize the effect of outliers. Panel A of Table 1 shows the sample selection process, with 2909 firm-year observations, and panel B shows the industry distribution of the sample. 
Table 1. Data Description.

\begin{tabular}{lcc}
\hline Panel A. Sample Selecting Process & & \\
\hline Initial observations from 2014 to 2018 (excluding business combination) & 7328 \\
\hline Less: & & 3362 \\
\hline Firms without Environmental Index & & 73 \\
\hline Closing fiscal year in months other than December/Financial companies & & 984 \\
\hline Companies with no financial statements and missing information & 2909 \\
\hline Final observation & & \\
\hline Panel B. Industry Distribution of the Sample & 24 & 0.83 \\
\hline Industry & 171 & 5.88 \\
\hline Agriculture/Forestry/Mining/Fishing & 113 & 3.88 \\
\hline Food/ Tobacco & 105 & 3.61 \\
\hline Textiles/Bags/Shoes & 671 & 23.07 \\
\hline Paper/Wood/ Pulp & 90 & 3.09 \\
\hline Chemicals/Plastics & 246 & 8.46 \\
\hline Non-metal & 694 & 23.86 \\
\hline Primary metals/Metals Working in Process & 35 & 1.20 \\
\hline Machinery/Biotech & 30 & 1.03 \\
\hline Furniture/Other Manufactures & 86 & 2.96 \\
\hline Electricity/Gas/Water/Waste/Environmental Clean & 245 & 8.42 \\
\hline Construction & 399 & 13.72 \\
\hline Wholesale/Retail & 2909 & 100 \\
\hline Service & & \\
\hline Total & & \\
\hline & & \\
\hline
\end{tabular}

\section{Empirical Results}

\subsection{Descriptive Statistics}

Table 2 presents the result of descriptive statistics for the variables used in this paper. The mean (median) values for ARND, E1, E2, and E3 are 0.467 (0.591), 0.427 (0.500), and 0.293 (0.200), respectively. The descriptive statistics for those variables shows that the average score for environmental performance strategy is 46 , while the environmental performance organization score is 42 and the stakeholder score is 29 .

Table 2. Descriptive Statistics.

\begin{tabular}{cccccc}
\hline Variables & Mean & STD & Q1 & Median & Q3 \\
\hline ARND & 0.118 & 0.322 & 0.000 & 0.000 & 0.000 \\
E1 & 0.467 & 0.360 & 0.000 & 0.591 & 0.800 \\
E2 & 0.427 & 0.316 & 0.000 & 0.500 & 0.700 \\
E3 & 0.293 & 0.323 & 0.000 & 0.200 & 0.600 \\
SIZE & 21.045 & 9.667 & 23.646 & 24.911 & 26.028 \\
ROA & 0.006 & 0.087 & 0.000 & 0.008 & 0.046 \\
MKT & 0.307 & 0.461 & 0.000 & 0.000 & 1.000 \\
LOSS & 0.244 & 0.430 & 0.000 & 0.000 & 0.000 \\
GROWTH & 0.010 & 0.241 & -0.091 & 0.018 & 0.115 \\
OCF & 0.042 & 0.080 & -0.001 & 0.042 & 0.088 \\
INVREC & 0.260 & 0.150 & 0.145 & 0.241 & 0.354
\end{tabular}

Notes: Variable definition: ARND = A dummy variable equal to 1 if the capitalized R\&D divided by the total assets is higher than the mean; E1 = Environmental performance strategy score; E2 = Environmental performance organization score; E3 = Environmental stakeholder score; HHI = Herfindahl-Hirshman Index; SIZE = Ln(total assets); ROA $=$ Net income/total assets; $\mathrm{MKT}=1$ if listed in Kosdaq; LOSS $=1$ for a company with losses, 0 otherwise; GROWTH = (Sales-Sales in prior year)/total assets; $\mathrm{OCF}=$ Operating cash flow/total assets; INVREC $=$ Plant, property, and equipment (except land and construction in progress)/total assets. 
Table 3 presents the correlation matrix of the variables used in this research. E1, the environmental performance, E2, the environmental organization, and E3, the environmental stakeholders, are positively related to R\&D capitalization. Significant positive correlations are seen between E1 and E2 and R\&D capitalization (ARND), but there is no significant correlation between E3 and R\&D capitalization.

Table 3. A Correlation Matrix.

\begin{tabular}{cccccc}
\hline & (1) & (2) & (3) & (4) & (5) \\
\hline \multirow{2}{*}{ (1) ARND } & 1.000 & 0.048 & 0.055 & 0.009 & 0.032 \\
& & 0.004 & 0.001 & 0.594 & 0.004 \\
(2) E1 & & 1.000 & 0.865 & 0.505 & 0.130 \\
& & & $<0.0001$ & $<0.0001$ & $<0.0001$ \\
(3) E2 & & & 1.000 & 0.582 & 0.112 \\
& & & & $<0.0001$ & $<0.0001$ \\
(4) E3 & & & & 1.000 & 0.046 \\
& & & & & 0.008 \\
(5) $\mathrm{HHI}$ & & & & & 1.000 \\
& & & & & \\
\hline
\end{tabular}

(1) See Table 2 for definitions of other variables.

\subsection{Regression Results}

In view of the possibility that residual data are not equally shared or that a correlation between the groups of residual data exists, firm-fixed effects are included in the regression model. The standard deviations, showing the time-series and cross-sectional correlations of the sample, predict the individual outcomes more accurately. Then, empirically-sound results are produced. Table 4 shows the result of fixed effects, suggesting a correlation between CER activities and R\&D capitalization, and this relationship is sustained in a highly competitive market.

Table 4. Regression results, firm-fixed effect.

\begin{tabular}{|c|c|c|c|c|c|c|}
\hline \multicolumn{7}{|l|}{ Panel A. H1 } \\
\hline \multirow{2}{*}{ Variables } & \multicolumn{2}{|c|}{ E1 } & \multicolumn{2}{|c|}{ E2 } & \multicolumn{2}{|c|}{ E3 } \\
\hline & Coefficient & $t$-Value & Coefficient & $t$-Value & Coefficient & $t$-Value \\
\hline Intercept & 0.354 & $2.83 * * *$ & 0.385 & $3.07 * * *$ & 0.469 & $3.70 * * *$ \\
\hline ARND & 0.032 & $1.91 * *$ & 0.052 & $2.60^{* * *}$ & 0.055 & $2.79 * * *$ \\
\hline SIZE & -0.006 & -1.17 & -0.007 & -1.46 & -0.010 & $-2.10 * *$ \\
\hline$R O A$ & -0.247 & $-2.19 * *$ & -0.247 & $-2.19 * *$ & -0.248 & $-2.17 * *$ \\
\hline$M K T$ & -0.114 & $-5.11^{* * *}$ & -0.114 & $-5.13^{* * *}$ & -0.115 & $-5.16 * * *$ \\
\hline LOSS & 0.002 & 0.09 & 0.001 & 0.05 & 0.000 & 0.01 \\
\hline GROWTH & 0.001 & 0.02 & 0.001 & 0.02 & 0.001 & 0.02 \\
\hline OCF & -0.021 & -0.21 & -0.019 & -0.20 & -0.017 & -0.18 \\
\hline INVREC & 0.008 & 0.21 & 0.007 & 0.19 & 0.027 & 0.72 \\
\hline Industry Dummy & \multicolumn{2}{|c|}{ Included } & \multicolumn{2}{|c|}{ Included } & \multicolumn{2}{|c|}{ Included } \\
\hline Year Dummy & \multicolumn{2}{|c|}{ Included } & \multicolumn{2}{|c|}{ Included } & \multicolumn{2}{|c|}{ Included } \\
\hline$F$-value & \multicolumn{2}{|c|}{$13.76^{* * *}$} & \multicolumn{2}{|c|}{$13.61^{* * *}$} & \multicolumn{2}{|c|}{$13.56^{* * *}$} \\
\hline Adj. $\mathrm{R}^{2}$ & \multicolumn{2}{|c|}{0.046} & \multicolumn{2}{|c|}{0.047} & \multicolumn{2}{|c|}{0.047} \\
\hline Observations & \multicolumn{2}{|c|}{2909} & \multicolumn{2}{|c|}{2909} & \multicolumn{2}{|c|}{2909} \\
\hline
\end{tabular}


Table 4. Cont.

\begin{tabular}{|c|c|c|c|c|}
\hline \multicolumn{5}{|l|}{ Panel B. H2-E1 } \\
\hline \multirow{2}{*}{ Variables } & \multicolumn{2}{|c|}{ High Competition } & \multicolumn{2}{|c|}{ Low Competition } \\
\hline & Coefficient & $t$-Value & Coefficient & $t$-Value \\
\hline Intercept & 0.221 & 1.41 & 0.211 & 1.01 \\
\hline$A R N D$ & 0.066 & $3.02 * * *$ & -0.015 & -0.58 \\
\hline SIZE & -0.005 & -0.93 & 0.005 & 0.56 \\
\hline$R O A$ & -0.356 & $-2.42 * *$ & -0.288 & $-1.65^{*}$ \\
\hline$M K T$ & -0.004 & -0.14 & -0.171 & $-5.36^{* * *}$ \\
\hline LOSS & -0.007 & -0.33 & -0.005 & -0.18 \\
\hline GROWTH & 0.011 & 0.25 & -0.005 & -0.09 \\
\hline OCF & 0.303 & $2.41^{* *}$ & -0.330 & $-2.19 *$ \\
\hline INVREC & -0.029 & -0.78 & 0.040 & 0.64 \\
\hline Industry Dummy & \multicolumn{2}{|c|}{ Included } & \multicolumn{2}{|c|}{ Included } \\
\hline Year Dummy & \multicolumn{2}{|c|}{ Included } & \multicolumn{2}{|c|}{ Included } \\
\hline$F$-value & \multicolumn{2}{|c|}{$5.33^{* * *}$} & \multicolumn{2}{|c|}{$10.31 * * *$} \\
\hline Adj. $R^{2}$ & \multicolumn{2}{|c|}{0.044} & \multicolumn{2}{|c|}{0.093} \\
\hline Observations & \multicolumn{2}{|c|}{1436} & \multicolumn{2}{|c|}{1473} \\
\hline \multicolumn{5}{|l|}{ Panel C. H2-E2 } \\
\hline \multirow{2}{*}{ Variables } & \multicolumn{2}{|c|}{ High Competition } & \multicolumn{2}{|c|}{ Low Competition } \\
\hline & Coefficient & $t$-Value & Coefficient & $t$-Value \\
\hline Intercept & 0.224 & 1.44 & 0.269 & 1.27 \\
\hline ARND & 0.075 & $2.88^{* * *}$ & 0.011 & 0.35 \\
\hline$S I Z E$ & -0.005 & -0.94 & -0.005 & -0.94 \\
\hline$R O A$ & -0.360 & $-2.43 * *$ & -0.360 & $-2.43^{*}$ \\
\hline$M K T$ & -0.005 & -0.17 & -0.005 & -0.17 \\
\hline LOSS & -0.007 & -0.36 & -0.007 & -0.36 \\
\hline GROWTH & 0.012 & 0.27 & 0.012 & 0.27 \\
\hline OCF & 0.304 & $2.42 * * *$ & 0.304 & $2.42 * *$ \\
\hline INVREC & -0.028 & -0.77 & -0.028 & -0.77 \\
\hline Industry Dummy & \multicolumn{2}{|c|}{ Included } & \multicolumn{2}{|c|}{ Included } \\
\hline Year Dummy & \multicolumn{2}{|c|}{ Included } & & \\
\hline$F$-value & & & & \\
\hline Adj. $R^{2}$ & & & & \\
\hline Observations & & & & \\
\hline Panel D. H2-E3 & & & & \\
\hline & High & & Low & tion \\
\hline Variables & Coefficient & $t$-Value & Coefficient & $t$-Value \\
\hline Intercept & 0.349 & $2.25^{* * *}$ & 0.364 & $1.67 *$ \\
\hline ARND & 0.091 & $3.77^{* * *}$ & 0.030 & 0.95 \\
\hline SIZE & -0.010 & $-1.76 *$ & -0.002 & -0.24 \\
\hline$R O A$ & -0.350 & $-2.35 * *$ & -0.275 & -1.58 \\
\hline$M K T$ & -0.010 & -0.37 & -0.173 & $-5.40 * * *$ \\
\hline LOSS & -0.008 & -0.39 & -0.006 & -0.23 \\
\hline GROWTH & 0.007 & 0.15 & -0.004 & -0.07 \\
\hline OCF & 0.305 & $2.43 * *$ & -0.328 & $-2.19 * *$ \\
\hline INVREC & 0.004 & 0.09 & 0.062 & 0.92 \\
\hline Industry Dummy & & & & \\
\hline Year Dummy & & & & \\
\hline$F$-value & & & & \\
\hline Adj. $\mathrm{R}^{2}$ & & & & \\
\hline Observations & & & & \\
\hline
\end{tabular}

$(1)^{*}, * *$, and ${ }^{* * *}$ indicate significance at the $10 \%, 5 \%$, and $1 \%$ levels, respectively. (2) See Table 2 for definitions of other variables. 
Table 4 is the result of the fixed effects, with results that are similar to the main result. This suggests a correlation between CER activities and R\&D capitalization, a relationship that is sustained in highly competitive markets, even when robustness is controlled. Table 4 also reports the result of Hypothesis 1 based on the estimation in Equation (2). Hypothesis 1 proposes that CER activities positively affect $R \& D$ capitalization. E1, E2, and E3 represent the environmental performance strategy, environmental performance organizations, and environmental performance shareholders, respectively.

As predicted, the result shows that the coefficient of E1 is 0.032 , which is positive and statistically significant. E1 stands for the environmental performance strategy score, and this result indicates that firms that have an environmental strategy in harmony with their basic management strategies and policies based on the willingness of top management are likely engaged in R\&D capitalization.

Table 4 also presents the coefficients of E2 and E3 as 0.052 and 0.055, respectively, and they are statistically significant at the $1 \%$ level. E2 stands for the environmental performance organization score. Its score indicates that firms are likely to set up an organization to implement environmental management systems and activities by the board of directors, decision-making organizations in environmental issues, and actual working organization, and that these firms are likely to capitalize on R\&D expenditures. E3, the environmental shareholder score, is also positively correlated with $R \& D$ capitalization. It indicates that firms likely to disclose information on the environment, as a means of communicating environmental issues and reflecting the opinion of shareholders, capitalize on R\&D expenditures.

These findings are consistent with the first hypothesis, suggesting that firms involved in CER activities in various areas, such as strategy, organization, and shareholders, are likely to capitalize on $R \& D$ expenditures. Each score evaluates CER activities in different aspects, and the aforementioned result supports Hypothesis 1 . Overall, disclosing information on companies working to improve environmental management shows that capitalizing R\&D expenditures have a positive impact on firm value. For example, many firms are now voluntarily agreeing to make efforts to minimize waste and pollution by adopting new environmentally-friendly management systems, and those systems include process and product innovation. To make the process more effective, investment in R\&D is necessary. Capitalizing R\&D carries the information that leads to the success of the projects, which in turn affects investors' beliefs about R\&D future payoffs [17]. Therefore, firms with CER activities and value-added activities are prone to capitalize on $R \& D$ expenditure in order to enhance firm value.

Examining Hypothesis 2, panel B of Table 4 shows the relationship between CER activities and $R \& D$ capitalization according to the degree of market competition. Firms are divided into two groups: high- and low-competition markets. The coefficients of E1, E2, and E3 in highly competitive markets are $0.066,0.075$, and 0.091 , respectively, and are significant at the $1 \%$ level. This result suggests that firms involved in CER activities likely capitalize on R\&D expenditures in a highly competitive market.

Product market competition acts as an external governance mechanism that forces managers to try and keep up with the competition. These good governance mechanisms improve oversight by external stakeholders and allow managers to work harder to meet the interests of external shareholders. Therefore, CER activities are more likely to involve R\&D capitalization when managers face discipline from a competitive market.

When a market is highly competitive, firms consider CER activities as a strategy for corporate sustainability. In other words, when a market is highly competitive, CER initiatives may act as additional product differentiators, since they add value to the core product attributes [18]. For example, a firm's strategy of lowering the gas emissions of its distribution network may serve as an additional differentiator and a potential cost saver (a modern distribution fleet of trucks uses less fuel and thus results in cost savings) [49]. Thus, high competition leads to investment in CER activities and improves the capability of technology via R\&D [7]. 


\subsection{Aggregate Measure of CER}

Table 5 is the first additional analysis, using an alternative measure of CER activities based on the sum of each score provided by the KCGS. Then, the correlation between the total score of CER activities and R\&D capitalization is examined.

Table 5. Regression results of the association between alternative measures of CER and R\&D capitalization.

\begin{tabular}{|c|c|c|c|c|}
\hline \multicolumn{5}{|l|}{ Panel A. H1 } \\
\hline Variables & \multicolumn{2}{|c|}{ Coefficient } & \multicolumn{2}{|c|}{$t$-Value } \\
\hline Intercept & \multicolumn{2}{|c|}{0.424} & \multicolumn{2}{|c|}{$3.60^{* * *}$} \\
\hline$A R N D$ & \multicolumn{2}{|c|}{0.058} & \multicolumn{2}{|c|}{$2.67^{* * *}$} \\
\hline Controls & \multicolumn{4}{|c|}{ Included } \\
\hline Industry Dummy & \multicolumn{4}{|c|}{ Included } \\
\hline Year Dummy & \multicolumn{4}{|c|}{ Included } \\
\hline$F$-value & \multicolumn{4}{|c|}{$6.80^{* * *}$} \\
\hline Adj. $R^{2}$ & \multicolumn{4}{|c|}{0.040} \\
\hline Observations & \multicolumn{4}{|c|}{2909} \\
\hline \multicolumn{5}{|l|}{ Panel B. H2 } \\
\hline \multirow{2}{*}{ Variables } & \multicolumn{2}{|c|}{ High Competition } & \multicolumn{2}{|c|}{ Low Competition } \\
\hline & Coefficient & $t$-Value & Coefficient & $t$-Value \\
\hline Intercept & 0.307 & $2.17^{* * *}$ & 0.217 & 1.09 \\
\hline$A R N D$ & 0.100 & $3.64^{* * *}$ & -0.001 & -0.03 \\
\hline Controls & \multicolumn{2}{|c|}{ Included } & \multicolumn{2}{|c|}{ Included } \\
\hline Industry Dummy & \multicolumn{2}{|c|}{ Included } & \multicolumn{2}{|c|}{ Included } \\
\hline Year Dummy & \multicolumn{2}{|c|}{ Included } & \multicolumn{2}{|c|}{ Included } \\
\hline$F$-value & \multicolumn{2}{|c|}{$3.47^{* * *}$} & \multicolumn{2}{|c|}{$7.60^{* * *}$} \\
\hline Adj. $R^{2}$ & \multicolumn{2}{|c|}{0.033} & \multicolumn{2}{|c|}{0.078} \\
\hline Observations & \multicolumn{2}{|c|}{1436} & \multicolumn{2}{|c|}{1473} \\
\hline
\end{tabular}

$(1)^{*}, * *$, and ${ }^{* * *}$ indicate significance at the $10 \%, 5 \%$, and $1 \%$ levels, respectively. (2) See Table 2 for definitions of other variables.

To calculate the total score, the scores of environmental performance strategy, organization, and shareholders are added together. Panel A shows the result of the association between total CER activities and R\&D capitalization. The coefficient of E, the total score of CER activities, is 0.058 , which is significantly positive. This result is consistent with Hypothesis 1.

Supported by good management theory, investment in CER activities is a value-increasing investment seeking better ways to improve social performances [1]. High-level management monitoring actions coupled with a clearer information environment should result in value creation by improving decision-making and leading to financial benefits [50].

$R \& D$ is a form of investment that enhances a firm's productivity and growth. Moreover, even though the R\&D accounting decision is left to the managers, capitalizing R\&D means that the project of a firm has earned technical feasibility, market feasibility, and will likely yield future benefits. Therefore, this implies that firms participating in CER activities are likely to capitalize on R\&D, leading to financial benefits [51].

Panel B shows the results of Hypothesis 2 using an alternative measure of CER activities. Firms are divided into two groups, based on the level of industry competition in the market. The coefficient of ARND is 0.100 in high-competition markets and -0.001 in low-competition markets. This result implies that managers in highly competitive industries are likely to improve a firm's performance by participating in CER activities as a strategy for sustainability and product differentiation [18]. Firms' 
$R \& D$ capitalization is the key to distinguishing them from other competitors, because it means that the project has earned technical feasibility and will likely lead to benefits in the near future.

\section{Conclusions}

In this study, we examine the association between CER activities and R\&D capitalization using data from firms-years between 2014 and 2018. CER activities refer to the efforts by companies to mitigate the negative impacts they may have on the environment. As predicted, firms engage in CER activities that affect $R \& D$ capitalization positively. CER activities are considered value-added activities that create firm value, thus enhancing the long-term value of the firm. Firms with environmental-focused efforts are likely to capitalize on R\&D, which results in knowledge enhancement that leads to environment-related processes and products. For example, firms with initiatives for reducing gas emissions that invest in $R \& D$ and are likely to capitalize $R \& D$ expenditures with the technical feasibility of the project, which will lead to future benefits.

Market competitiveness is also considered in this study. In highly competitive markets, managers are incentivized to perform at a high level, and conducting CER activities allows firms to differentiate themselves from the competition. Therefore, in highly competitive markets, firms participating in CER activities tend to capitalize on R\&D. These results are robust when an alternative measure of CER activities is used.

In conclusion, this study has important implications for management, namely that R\&D capitalization is connected to CER activities and offers a competitive advantage for firms. Furthermore, firms should make an effort to accept their responsibilities as members of society as a whole, by looking beyond short-term profits and working instead toward building sustainable operations and relationships with stakeholders.

This study contributes to the literature in the following aspects. First, the findings of this study should make firms consider employing R\&D capitalization when developing their environmental strategies, since innovation is already an environmentally friendly activity in and of itself. Innovative firms should focus, therefore, on identifying and capitalizing on opportunities to promote environmentally responsible activities in their R\&D processes. Investment in CER activities is more beneficial to a firm when its managers have a comprehensive understanding of the ways in which specific types of CER activities affect financial performance within specific industries. This finding has important implications for managers who determine the allocation of resources, especially when resources are limited, in which case it may be more beneficial for managers to allocate those limited resources only to the most beneficial CER activities.

Second, this study aims to analyze, in detail, the association between CER activities and R\&D capitalization. Previous studies have investigated CER activities in general, and information is hidden when using an aggregate measure of CER activities. In other words, in analyzing the association between CER activities in general and R\&D capitalization, the use of total CER activities by itself is limited in that it cannot identify the differences among CER indices. To fill the gap in the previous literature, this study investigates the relationship between CER activities and R\&D capitalization by using detailed measures of CER activities provided by the KCGS, such as environmental strategy, organization, and shareholders. This study provides, therefore, a detailed and intuitive analysis.

Our findings are subject to several limitations, including measurement errors regarding the level of competition. There are possible omitted variables that may have led to errors. In terms of the control variables, they are estimated coefficients with uniform size, directionality, and significance throughout the model specification, so the control variables may be correlated with the main explanatory variables. We expect future research papers to resolve these potential problems. Nevertheless, the empirical findings suggest that firms actively involved in CER activities tend to capitalize on R\&D expenditures and product market competition, which acts as an external governance mechanism and may generate positive consequences for managers' investment in the environment. We believe that the results in this study are important and provide several valuable insights into the positive effect of product 
market competition on the environment, especially for regulatory bodies, managements, and other outside investors.

Author Contributions: Conceptualization, J.L.; methodology, J.L.; software, J.L.; validation, J.L. and S.K.; formal analysis, J.L.; investigation, J.L.; resources, J.L.; data curation, J.L.; writing-original draft preparation, S.K.; writing-review and editing, S.K.; supervision, J.L. and S.K. The two authors contributed equally to the manuscript. All authors have read and agreed to the published version of the manuscript.

Funding: This research received no external funding.

Conflicts of Interest: The authors declare no conflict of interest.

\section{References}

1. Waddock, S.A.; Graves, S. The corporate social performance-financial performance link. Strateg. Manag. J. 1997, 18, 303-319. [CrossRef]

2. Bowen, H.R. Social Responsibilities of the Businessman; Harper \& Row: New York, NY, USA, 1953.

3. Yon Hap News. Incentives for Partners to Create Social Value; Yon Hap News: Seoul, Korea, 2020.

4. Cuerva, M.C.; Triguero-Cano, Á.; Corcoles, D. Drivers of green and non-green innovation: Empirical evidence in Low-Tech SMEs. J. Clean. Prod. 2014, 68, 104-113. [CrossRef]

5. World Business Council for Sustainable Development. Corporate Social Responsibility: Meeting Changing Expectations; World Business Council for Sustainable Development: Geneva, Switzerland, 1999.

6. World Business Council for Sustainable Development. Corporate Social Responsibility: Making Good Business Sense; World Business Council for Sustainable Development: Geneva, Switzerland, 2000.

7. Ferri, G.; Pini, M. Environmental vs. social responsibility in the firm. Evidence from Italy. Sustainability 2019, 11, 4277. [CrossRef]

8. Aguado, E.; Holl, A. Differences of corporate environmental responsibility in small and medium enterprises: Spain and Norway. Sustainability 2018, 10, 1877. [CrossRef]

9. Lopez-Gamero, M.D.; Molina-Azorin, J.F.; Claver-Cortes, E. The whole relationship between environmental variables and firm performance: Competitive advantage and firm resources as mediator variables. J. Environ. Manag. 2009, 90, 3110-3121. [CrossRef] [PubMed]

10. Matei, M.; Voica, M.C. Social responsibility in the financial and banking sector. Econ. Insights Trends Chall. 2013, 2, 115-123.

11. Sun, W.-C.; Huang, H.-W.; Dao, M.; Young, C.-S. Auditor selection and corporate social responsibility. J. Bus. Financ. Account. 2017, 44, 1241-1275.

12. Saez-Martínez, F.J.; Gonzalez-Moreno, A.; Hogan, T. The role of the university in eco-entrepreneurship: Evidence from the Eurobarometer survey on attitudes of European entrepreneurs towards eco-innovation. Environ. Eng. Manag. J. 2014, 13, 2541-2549.

13. Horbach, J.; Rammer, C.; Rennings, K. Determinants of eco-innovations by type of environmental impact-The role of regulatory push/pull, technology push and market pull. Ecol. Econ. 2012, 78, 112-122. [CrossRef]

14. Oswald, D.R.; Zarowin, P. Capitalization vs. Expensing of R\&D and Earnings Management. In Working Paper; New York University: New York, NY, USA, 2007.

15. Hughes, J.S.; Kao, J.L. Economics implications of alternative disclosure rules for research and development costs. Contemp. Account. Res. 1991, 8, 152-169. [CrossRef]

16. Wyatt, A. Accounting recognition of intangible assets: Theory and evidence on economic determinants. Account. Rev. 2005, 80, 967-1003. [CrossRef]

17. Mohd, E. Accounting for software development costs and information asymmetry. Account. Rev. 2005, 80, 1211-1231. [CrossRef]

18. McWilliams, A.; Siegel, D.S. Corporate Social Responsibility: A Theory of the Firm Perspective. Acad. Manag. Rev. 2001, 26, 117-127. [CrossRef]

19. Feng, M.; Wang, X.; Kreuze, J. Corporate social responsibility and firm financial performance: Comparison analyses across industries and CSR categories. Am. J. Bus. 2017, 32, 106-133. [CrossRef]

20. Suganthi, L. Examining the relationship between corporate social responsibility, performance, employees' pro-environmental behavior at work with green practices as mediator. J. Clean. Prod. 2019, 232, 739-750. [CrossRef] 
21. Orazalin, N.; Baydauletov, M. Corporate social responsibility strategy and corporate environmental and social performance: The moderating role of board gender diversity. Corp. Soc. Responsib. Environ. Manag. 2020, 1, 1-13. [CrossRef]

22. Zeng, S.; Qin, Y.; Zeng, G. Impact of corporate environmental responsibility on investment efficiency: The moderating roles of the institutional environment and consumer environmental awareness. Sustainability 2019, 11, 4512. [CrossRef]

23. Yang, Y. Reliability of R\&D capitalization: Evidence from ex post impairment in China. China J. Account. Res. 2019, 12, 251-269.

24. Financial Accounting Standards Board (FASB). Statement of Financial Accounting Standards No. 2, Accounting for Research and Development Costs; FASB: Norwalk, CT, USA, 1974.

25. Financial Accounting Standards Board (FASB). Statement of Financial Accounting Standards no. 86, Accounting for the Costs of Computer Software to be Sold, Leased, or Otherwise Marketed; FASB: Norwalk, CT, USA, 1985.

26. International Accounting Standards Board (IASB). International Accounting Standards No. 38, Intangible Assets; IASB: London, UK, 1998.

27. Financial Accounting Standards Board (FASB). Proposal for a New Agenda Project-Disclosure of Information About Intangible Assets Not Recognized in Financial Statements; FASB: Norwalk, CT, USA, 2001.

28. Ciftci, M.; Zhou, N. Capitalizing R\&D expenses versus disclosing intangible information. Rev. Quant. Financ. Account. 2016, 46, 661-689.

29. Healy, P.M.; Myers, S.C.; Howe, C.D. R\&D accounting and the tradeoff between relevance and objectivity. J. Account. Res. 2002, 40, 677-710.

30. Padgett, R.; Galan., J. The effect of R\&D intensity on CSR. J. Bus. Ethics 2010, 93, 407-418.

31. Chen, E.G.I.; Lev, B. The positive externalities of IFRS R\&D capitalization: Enhanced voluntary disclosure. Rev. Account. Stud. 2017, 22, 677-714.

32. Lee, N. R\&D Accounting Treatment, R\&D State and Tax Avoidance: With a Focus on Biotech Firms. Sustainability 2018, 11, 44 .

33. Percy, M. Financial reporting discretion and voluntary disclosure: Corporate research and development expenditure in Australia. Asia-Pac. J. Account. Econ. 2000, 7, 1-31. [CrossRef]

34. Markarian, G.; Pozza, L.; Prencipe, A. Capitalization of R\&D costs and earnings management: Evidence from Italian listed companies. Int. J. Account. 2008, 43, 246-267.

35. EI Ghoul, S.E.; Chuck, C.Y.; Mishra, R. Does corporate social responsibility affect the cost of capital? J. Bank. Financ. 2011, 35, 2388-2406. [CrossRef]

36. McWilliams, A.; Siegel, D.S. Corporate Social Responsibility and Firm Financial Performance. Strateg. Manag. J. 2000, 21, 602-609. [CrossRef]

37. Alchian, A. Uncertainty, evolution and economic theory. J. Political Econ. 1950, 58, 211-221. [CrossRef]

38. Hart, O.D. The market mechanism as an incentive scheme. Bell J. Econ. 1983, 14, 366-382. [CrossRef]

39. Karuna, C. Industry product market competition and managerial incentives. J. Account. Econ. 2007, 43, 275-297. [CrossRef]

40. Sheikh, S. The impact of market competition on the relation between CEO power and firm innovation. J. Multinatl. Financ. Manag. 2018, 44, 36-50. [CrossRef]

41. Fisman, R.; Heal, G.; Nair, V. A model of corporate philanthropy. In Working Paper; Columbia University: New York, NY, USA, 2008.

42. Declerck, M.; M'Zali, D. Product market competition and corporate social responsibility. In Working Paper; University Paris, Panthéon-Sorbonne: Paris, France, 2012.

43. Siegel, D.S.; Vitaliano, D.F. An empirical analysis of the strategic use of corporate social responsibility. J. Econ. Manag. Strategy 2007, 16, 773-792. [CrossRef]

44. Russo, M.V.; Fouts, P.A. A resource-based perspective on corporate environmental risk management and profitability. Acad. Manag. J. 1997, 40, 534-559.

45. Ryu, D.; Ryu, D.; Hwang, J.H. Corporate social responsibility, market competition, and shareholder wealth. Invest. Anal. J. 2016, 45, 16-30. [CrossRef]

46. Sutton, J. Quality, trade and the moving window: The globalization process. Econ. J. 2007, 117, 469-498. [CrossRef]

47. Petersen, M.A.; Rajan, R. The effect of credit market competition on lending relationships. Q. J. Econ. 1995, 110, 407-443. [CrossRef] 
48. Jung, S.; Kim, S.; Yim, J. The effect of asset-counted R\&D expenditures and cost-counted R\&D expenditures on credit ratings. J. Int. Trade Commer. 2018, 14, 571-584.

49. Kemper, K.; Schilke, O.; Reimann, M.; Wang, X.; Brettel, M. Competition-motivated corporate social responsibility. J. Bus. Res. 2013, 66, 1954-1963. [CrossRef]

50. Cook, K.; Romi, A.M.; Sanchez, D. The influence of corporate social responsibility on investment efficiency and innovation. J. Bus. Financ. Account. 2019, 46, 494-537. [CrossRef]

51. Sharfman, M.P.; Fernado, C.S. Environmental risk management and the cost of capital. Strateg. Manag. J. 2008, 29, 569-592. [CrossRef]

(C) 2020 by the authors. Licensee MDPI, Basel, Switzerland. This article is an open access article distributed under the terms and conditions of the Creative Commons Attribution (CC BY) license (http://creativecommons.org/licenses/by/4.0/). 